\title{
直接焼入プロセスにおけるボロンの粒界 偏析挙動と焼入性

\section{Relation between Hardenability and Segregation to Austenite Grain Boundaries of Boron Atom on Direct Quenching Process}

Yoshihiko Kamada, Hirofumi Kurayasu and Seiichi Watanabe

\begin{abstract}
Synopsis :
The effect of boron (B) on hardenability is explained by the decrease of boundary energy due to the segregation of $B$ atoms to austenite grain boundaries. In this paper, the effect of niobium $(\mathrm{Nb})$ on hardenability of $B$ treated direct quenching steel is studied with varing the condition of B segregation to austenite boundaries. And it is clarified that the effect of $\mathrm{B}$ on hardenability is fully obtained even at unrecrystallized state of austenite, and that the maximum hardenability in direct quenching process can be attained at about $10 \mathrm{ppm}$ soluble $\mathrm{B}$ which is about three times as the optimum ones of conventional reheat quenching process. It is concluded that the addition of $0.015 \% \mathrm{Nb}$ rather give rise to the hardenability of $\mathrm{B}$ even in unrecrystallized state of austenite in direct quenching process because $\mathrm{Nb}$ hinders boundary migration of austenite and enables soluble B to segregate to the grain boundaries and deformation bands.
\end{abstract}

Key words : plate ; high strength low alloy steel ; segregation ; strength ; hardenability.

\section{1. 緒言}

ボロン（B）の焼入性向上効果はオーステナイト $(\gamma)$

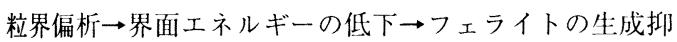
制とする機構 ${ }^{1)}$ が有力であるが，完全には実証されてい ない. しかしBは微量で高い焼入性问上効果を発揮する ため多くの調質鋼に適用されてきた 2 .ここれまでのBの 焼入性向上効果についての検討は, 焼入時の加熱温度で アルミニウム $(\mathrm{Al})$, チタ二ウム $(\mathrm{Ti})$ などの微量添加 元素と窒素 $(N)$ との授受を通して存在する固溶Bが $\gamma$ 粒界に平衡偏析するという観点からが主体であり, 粒界 の移動をともなう㨁接焼入プロセスにおけるBの焼入性 向上効果の検討はまだ不十分である ${ }^{3)}$. すなわち, 圧延 加工中あるいは压延加工後のBの粒界偏析挙動は $\gamma$ 粒の 再結晶挙動に大きく左有されることが知られてきてお $\eta^{4)}$-6), 㨁接烧入プロセスにおけるBの焼入性向上効果 については従来の再加熱焼入れのような平衡論的な Bの 取扱いとはことなり加】 $\gamma$ 粒の再結晶による粒界移動と Bの搪散による粒界偏析との競合という速度論的な観点
からの検討が必要である．本報告では $\mathrm{Nb}$ 量および圧延 仕上温度を変えることにより圧延後の $\gamma$ の再結晶挙動を コントロールし，Bの粒界偏析状態を变え直接焼入プロ セスにおけるBの偏析挙動と焼入性について検討したも のである。

\section{2. 実 験 方 法}

供試材は $0.08 \%$ C- $0.25 \% \mathrm{Si}-1.4 \% \mathrm{Mn}-0.002 \%$ $\mathrm{P}-0.002 \% \mathrm{~S}$ を基本成分とし, Table 1 に示すような微

Table 1. Chemical composition (wt \%).

\begin{tabular}{l|ccccc|c}
\hline No. & Sol. Al. & $\mathrm{Ni}$ & $\mathrm{Ti}$ & $\mathrm{B}$ & $\mathrm{N}$ & - \\
\hline H22 & 0.046 & 0.014 & 0.012 & 0.0013 & 0.0008 & \\
H19 & 0.045 & 0.015 & 0.011 & 0.0013 & 0.0019 & \\
H20 & 0.045 & 0.015 & 0.012 & 0.0014 & 0.0048 & \\
H21 & 0.047 & 0.012 & 0.013 & 0.0013 & 0.0072 & NbTiB \\
H51 & 0.051 & 0.002 & 0.009 & 0.0007 & 0.0016 & \\
H52 & 0.051 & 0.006 & 0.009 & 0.0007 & 0.0013 & \\
H53 & 0.051 & 0.009 & 0.009 & 0.0008 & 0.0017 & \\
H54 & 0.051 & 0.030 & 0.010 & 0.0006 & 0.0017 & \\
\hline H48 & 0.050 & $<0.002$ & 0.006 & 0.0008 & 0.0015 & TiB \\
H11 & 0.038 & 0.012 & 0.011 & $<0.0001$ & 0.0019 & NbTi \\
H35 & 0.025 & $<0.002$ & 0.007 & $<0.0001$ & 0.0051 & Base \\
\hline
\end{tabular}

昭和 62 年 4 月・ 10 月本会講演大会にて発表 昭和 62 年 12 月 21 日受付 (Received Dec. 21，1987)

* 住友金属工業(株)鉄鋼技術研究所（Iron \& Steel Research Laboratories, Sumitomo Metal Industries, Ltd., 1-3 Nishinagasuhondori Amagasaki 660)

*2 住友金属.L業(株)未来技術研究所 (Advanced Technology Research Laboratories, Sumitomo Metal Industries, Ltd.)

*3 住友金属工業(株)未来技術研究所工博 (Advanced Technology Research Laboratories, Sumitomo Metal Industries, Ltd.) 
量添加元素を含有する $\mathrm{NbTiB}$ 鋼, TiB 鋼, NbTi 鋼の 3 種類である.いずれも真空溶解により $150 \mathrm{~kg}$ 鋼塊に 溶製した。ここで $\mathrm{Ti}$ は単に固溶 $\mathrm{N}$ t TiN として固定 するために添加しており $0.01 \%$ をべースとしている. 溶製後これらを $150 \mathrm{~mm}$ 厚 $\times 100 \mathrm{~mm}$ 幅に鍛造し圧延実 験に供した。この鍛造材を 15 パスの熱間压延により 38 $\mathrm{mm}$ 厚に仕上げ約 $10 \mathrm{~s}$ 後に水冷し室温まで泠却した。 その時の冷却速度は板厚中心部 $11^{\circ} \mathrm{C} / \mathrm{s}$ であつた. 圧延 加工は仕上温度 $(F / T)$ と $F / T+100^{\circ} \mathrm{C}$ の温度域で $68 \%$ の加工を与える調整压延を実施した。この時の加 熱温度・仕上温度を変化させ各供試鋼の強度・勒性にお よぼす压延条件の影響を調查した。さらに淔接焼入材を 用い, 光学顕微鏡および電子顕微鏡によるミク口組織観 察と Fission Track Etching (FTE) 法 ${ }^{7}$ によるBの偏 析状態の観察を行つた。また， Bの化合状態別定量分 析8)を行い直接焼入プロセスにおけるBの存在状態と焼 入性向上効果の関係を検討した。また，本圧延材から 8 $\mathrm{mm} \phi \times 12 \mathrm{~mm}$ の試験片を採取し熱間加工再現装置（富 土電波製 THERMECMASTER-Z）を用いて二段圧縮加 工する中断再負荷試験を行い ${ }^{9)}$, 次式で示される軟化度 $(X s)$ を測定することにより加I／の再結晶過程を調查 した.

$$
X s=\left(\sigma_{m}-\sigma_{2}\right) /\left(\sigma_{m}-\sigma_{1}\right)
$$

$\sigma_{1}, \sigma_{m}$ は扔の㧍の一段目の熱間加厂時の降伏応力と負荷 中断時の歪みにおける变形応力， $\sigma_{2}$ は二段目加工時の 降伏応力である。

\section{3. 実 験 結 果}

\section{$3 \cdot 1$ 直接焼入焼もどし時の加熱・圧延条件と強度・靶 性}

Fig. 1 に直接焼入焼もどし鋼の強度・勒性に及ぼす 加熱・压延条件の影響について, 窒素 $(\mathrm{N})$ 量の異なる $\mathrm{NbTiB}$ 鋼を用いて調查した結果を示す。加熱温度の上 昇は強度の増加とそれに伴う低温鞁性（破面遷移温度： ${ }_{v} T_{s}$ ) の劣化を示す。しかし， $1050^{\circ} \mathrm{C}$ を超える加熱では 強度増加は飽和傾向を示すが低温靫性の劣化は依然とし て生じる. $\mathrm{N}$ 量に着目すると, $20 \mathrm{ppm}$ 米満 (H 19, H 22) の場合は加熱温度の上昇につれ強度増加が大きく, 40 ppm を超える (H 20, H 21) の場命は強度上昇は少ない のに低温靶性の劣化が著しい。什上温度の依存性につい ても $\mathrm{N}$ 量の影響が認められ; $20 \mathrm{ppm}$ 未満の場合 $800^{\circ} \mathrm{C}$ 付近の仕上温度で最高強度を示し低温鞋性も良好とな る. $40 \mathrm{ppm}$ を超える場合は仕上温度の低下に伴い強度 は低下寸るが，同様に $800^{\circ} \mathrm{C}$ 仕上時に最良の低温䩲性 を示す. Fig. 2 に直接焼入材を用いて非水溶媒電解抽

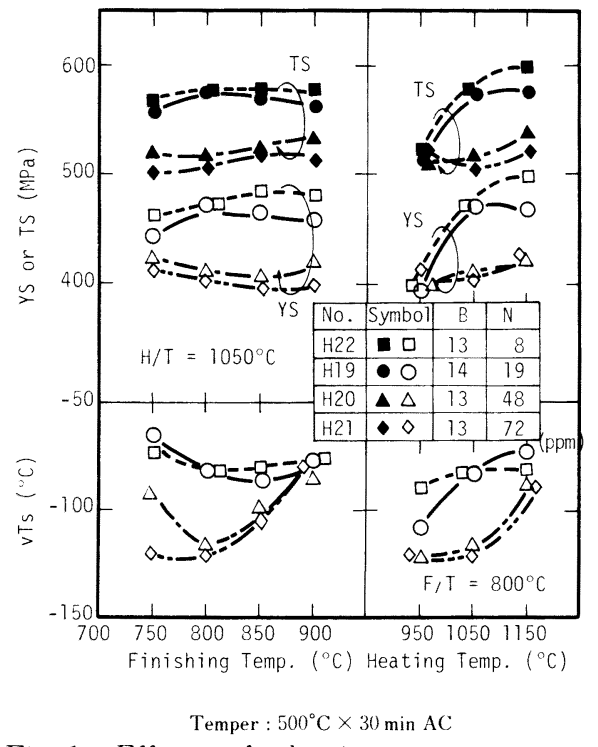

Fig. 1. Effect of heating temperature and finishing temperature on mechanical properties of direct quench and temper processed NbTiB steels with various $\mathrm{N}$ content.

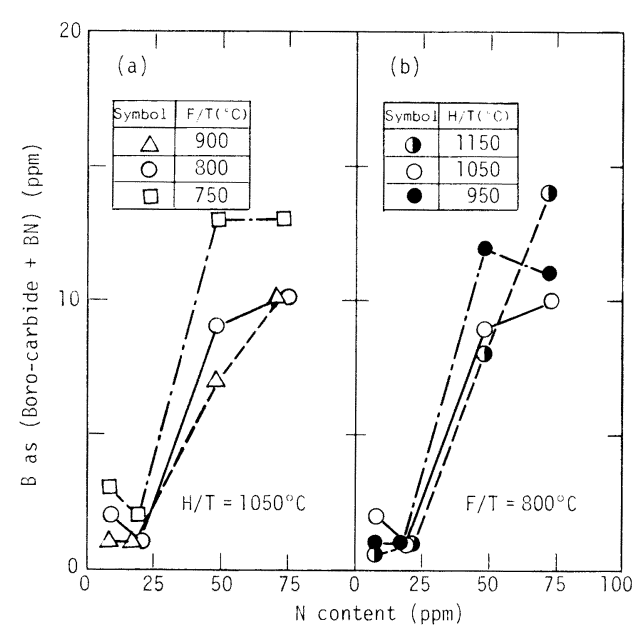

Fig. 2. Relation $\mathrm{B}$ as (Boro-carbide $+\mathrm{BN}$ ) and $\mathrm{N}$ content in various heating temperture $(H / T)$ and roll finishing temperature $(F / T)$.

出（1％テトラメチルアンモニウムクロライド+10\%ア セチルアセトン メタノール溶液, 電流密度 $=20$ $\left.\mathrm{mA} / \mathrm{cm}^{2}\right)$ を行い, 残椬中のB化命物 (BN + Borocarbide) として捕らえられた B を蒸留分離クルクミン 吸光光度法9) で定量し, $\mathrm{N}$ 量と加熱温度抢よび什上温度 で整理した。低 $\mathrm{N}$ 側ではB化命物の存在は認められず高 


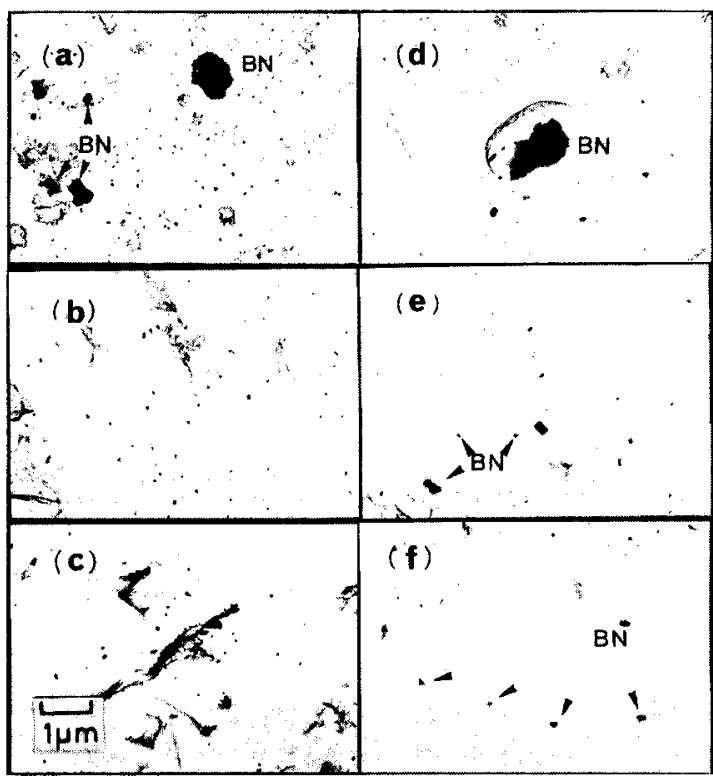

(a) $950^{\circ} \mathrm{C}$ (b) $1050^{\circ} \mathrm{C}$ (c) $\perp 150^{\circ} \mathrm{C}: \mathrm{H} 19(19 \mathrm{ppm} \mathrm{N})$ (d) $950^{\circ} \mathrm{C}$ (e) $1050^{\circ} \mathrm{C}$ (f) $1150^{\circ} \mathrm{C}: \mathrm{H} 20(48 \mathrm{ppm} \mathrm{N})$

Photo. 1. Change in $\mathrm{B}$ compounds with heating temperature in direct quenched NbTiB steels.

N側でははとんどが化合物を形成している，すなわち固 溶Bが存在しBの焼入性淌上効果が発揮されているか否 かで Fig. 1の強度変化は説明できる，加熱温度が高い ほどB化合物の量が減少するのは, Photo. 1 の抽出レ プリカ写真に示すように未固溶の粗大B化合物の減少に 対応する. しかし，B化合物が分解して固溶Bが増えて も高 N領域ではひき続く压延・焼入工程で容易に BN を形成し焼入性の向上には寄与しない。とくにN量が

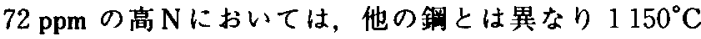
加熱時にB化合物が逆に增加する（Fig. 2(b)).これ は AlN の固溶により固溶Nが増加し压延・焼入.程で BN が析出することに対応する. Fig. 2（a ）にB化合 物として捕らえられた $\mathrm{B}$ 量と $\mathrm{N}$ 量の関係を各仕上温度ご とに整理した，仕上温度の低下に伴いB化合物は増加し 固溶 B 量の低下を招いている。この傾向は高 N 側で顥著 であり，仕上温度の低下に伴う強度低下とよく対応する。 これは直接焼入プロセスにおけるBの烧入性向上効果は 仕上温度における固溶B量に支配されることを示唆する ものである。しかし低N側では逆に低温 $\gamma$ 域仕上げほど 強度上昇しており，固溶B量の変化のみから説明できな い. Photo. 2 は仕上温度を変化させた時のミクロ組織 の変化を示すが, 高N側では高温 $\gamma$ 域仕上げはどフェラ

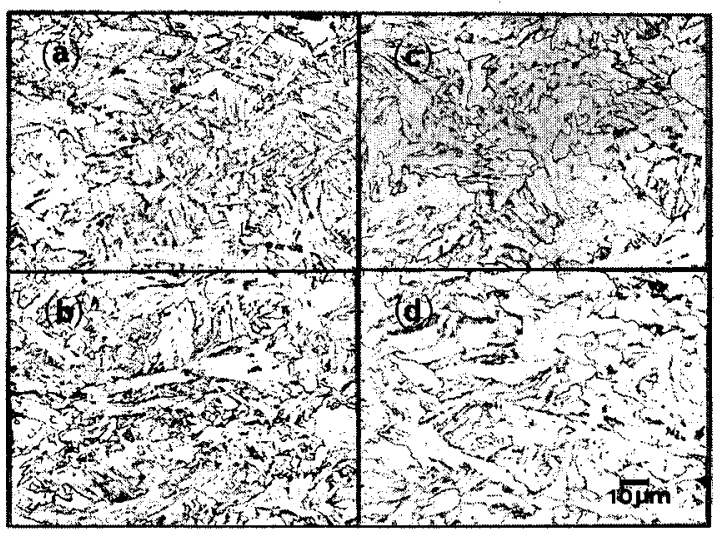

(a) $900^{\circ} \mathrm{C}$ (b) $800^{\circ} \mathrm{C}: \mathrm{H} 19(19 \mathrm{ppm} \mathrm{N})$

(c) $900^{\circ} \mathrm{C}$ (d) $800^{\circ} \mathrm{C}: \mathrm{H} 20(48 \mathrm{ppm} \mathrm{N})$

Photo. 2. Change in optical microstructure with roll finishing temperature in direct quenched NbTiB steels.

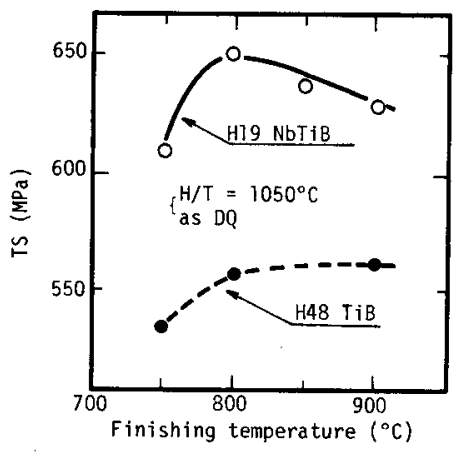

Fig. 3. Effect of finishing temperature on tensile streagth of direct quenched $\mathrm{NbTiB}$ and TiB steels.

イトの生成は抑制されているのに対し低N側では低温 $\gamma$ 域仕上げはどべイナイトは密な組織へと変化しており仕 上温度依存性は両者で相反する傾向を示している．低N 側の $800^{\circ} \mathrm{C}$ 仕上げでは未再結晶領域からの焼入れであ り，フェライトの核生成サイト增加に伴う焼入性低下が 孙想されるのに逆に焼入性は高い結果となつている。

\section{$3 \cdot 2$ 仕上温度の強度に及ぼす影筆}

Fig. 3 に直接焼入鍓の強度の仕上温度依存性を $\mathrm{NbTiB}$ 銅と TiB 鋼を比較して示す. TiB 鋼が高温 $\gamma$ 域 仕上げほど強度が高いのに対し，NbTiB 鋼は低温 $\gamma$ 域 仕上げはど強度が高い．Fig. 4 に $\mathrm{Nb}$ 添加による強度 上昇を $\mathrm{NbTiB}$ 铜と NbTi 銅で比較して示す. Nb 添加 による直接焼入時の強度上昇は B の添加有無により変化 しBと共存するとその強度上昇は大きくなる，しかし， 


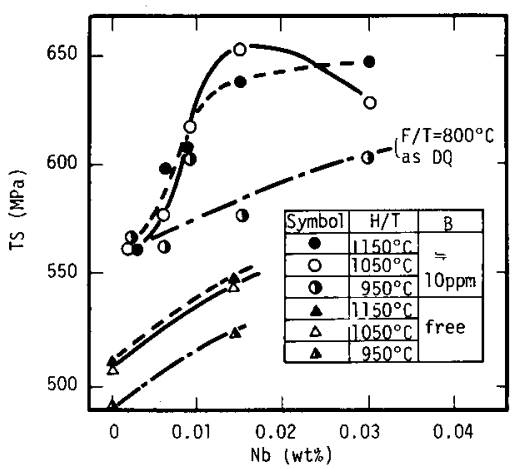

Fig. 4. Effect of $\mathrm{Nb}$ addition on tensile strength of direct quenched $\mathrm{NbTiB}$ and $\mathrm{NbTi}$ steels.

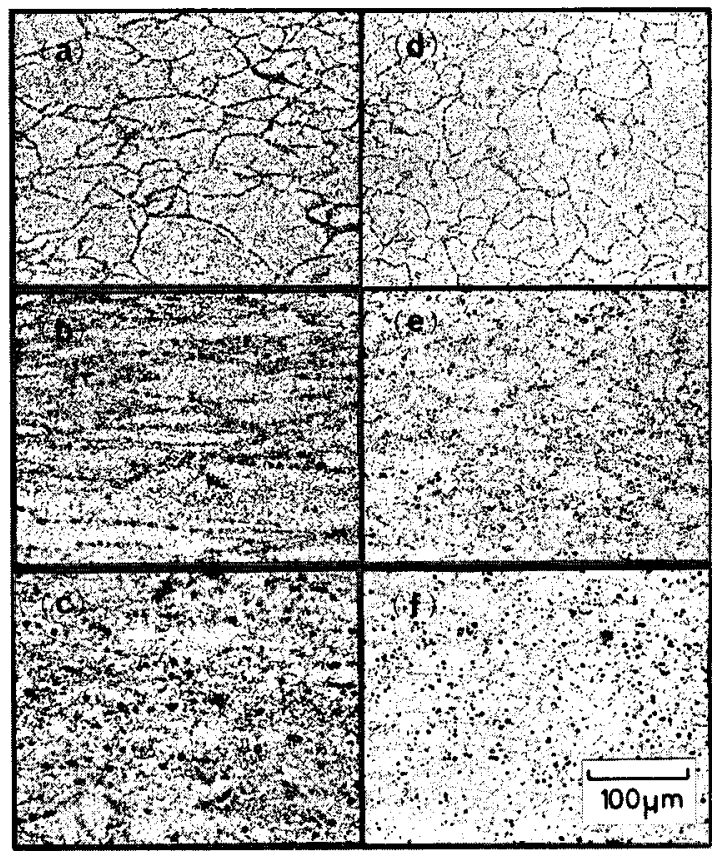

(a) $900^{\circ} \mathrm{C}$ (b) $800^{\circ} \mathrm{C}$ (c) $750^{\circ} \mathrm{C}: \mathrm{NbTiB}$ (H19)

(d) $900^{\circ} \mathrm{C}$ (e) $800^{\circ} \mathrm{C}$ (f) $750^{\circ} \mathrm{C}: \mathrm{TiB}(\mathrm{H} 48)$

Photo. 3. Change in distribution of $B$ atoms with roll finishing temperature in direct quenched $\mathrm{NbTiB}$ and $\mathrm{TiB}$ steels.

この強度上昇は $\mathrm{Nb}$ の固溶がはかられる $1050^{\circ} \mathrm{C}$ 以上の 高温加熱時のみに生し， $950^{\circ} \mathrm{C}$ 加熱ではその効果は消失 している.これは $\mathrm{Nb}$ の固溶による焼入性向上効果がそ の一因と考えられるが, 逆に $\mathrm{Nb}$ が固溶し固溶 $\mathrm{Nb}$ の存 在と加工中あるいは加工後に析出する $\mathrm{Nb}$ 炭窒化物に起 因する再結晶抑制効果から生じる未再結晶 $\gamma$ からの焼入

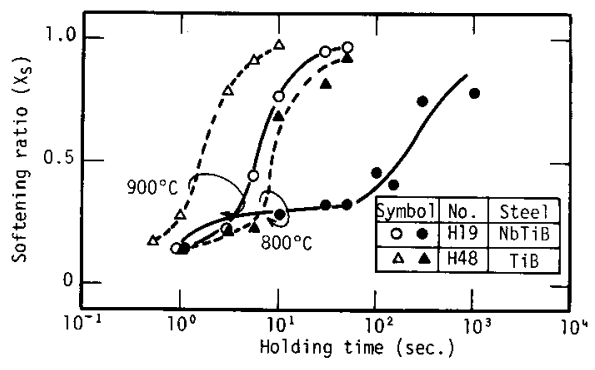

Fig. 5. Difference in softening behaviour of $\mathrm{NbTiB}, \mathrm{TiB}$ steel with deformation temperature.

れでも固溶 $\mathrm{B} か ゙$ 共存すると焼入性が向上することを示唆 するものである. Photo. 3 に FTE 法でBの分布状態を 観察した結果を示す． $\mathrm{TiB}$ 鋼の $900^{\circ} \mathrm{C}$ 仕上げではポリ ゴナルな旧 $\gamma$ 粒界への明瞭な偏析が観察されるが，仕上 温度低下に伴い不明瞭なものへと変化している. しかし $800^{\circ} \mathrm{C}$ 仕上げでは一部旧 $\gamma$ 粒界に偏析している様子が箱 えるが，全粒界を覆うまでには至つていない． $750^{\circ} \mathrm{C}$ 仕 上げでは 2 相域仕上げのため,フェライト析出により オーステナイト中とフェライト中のBの溶解度の差から B化合物生成が促進され焼入性向上効果を失つて塊状の ランダムな析出状態を生しててる。 $\mathrm{NbTiB}$ 鋼の $900^{\circ} \mathrm{C}$ 仕上げでも同様に比較的ポリゴナルな旧 $\gamma$ 粒界へBが偏 析しているのが観察される。しかし $800^{\circ} \mathrm{C}$ 仕上げでは パンケーキ状の $\gamma$ 粒界と粒内の变形帯と考えられる場所 にBが偏析している. $750^{\circ} \mathrm{C}$ 仕上げでは 2 相域仕上げの ため $\mathrm{TiB}$ 鋼と同様不明瞭な偏析状態となつている. 次 に本供試鋼の $900^{\circ} \mathrm{C}$ と $800^{\circ} \mathrm{C}$ に㧍ける熱間加工時の軟 化挙動を Fig. 5 に示す. 本圧延条件をシミュレートす る目的で, 加熱温度は $1050^{\circ} \mathrm{C} \times 5 \mathrm{~min}$, 一段目圧縮 $0.67(12 \mathrm{~mm} \rightarrow 6 \mathrm{~mm})$, 歪布速度 $\dot{\varepsilon}=1 / \mathrm{s}$ とした。これか ら两鎆とも $900^{\circ} \mathrm{C}$ では $10 \mathrm{~s}$ 以内に $X s=0.7$ 以上の軟化 を示しており，十分に加工再結晶している，従って，実 際の圧延時の $900^{\circ} \mathrm{C}$ 什.上げでは压延 $10 \mathrm{~s}$ 後に水冷され て扰り加工再結昆後に焼入れされたことを示している.

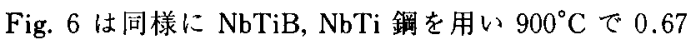
の圧紑加工を加えた後，同一温度で保持後 $\mathrm{He}$ ガスで焼 入れして保持時問に対する強度変化と軟化挙動の対比を 示す。これより $\mathrm{NbTiB}$ 鋼においては再結晶途上の焼人 性は少り, 再結晶淔後に強度のピークが認められる。こ こで保持時間 $10 \mathrm{~s}$ 後の焼入試験片の組織観察ではポリ ゴナルな微紏 $\gamma$ 粒が観察されており再結晶はすでに完了 していることが確認されている。この時 $X s=0.75$ と 1 より低い值となるのは再結晶後の $\gamma$ 粒が微細化し， $\sigma_{2}$ 


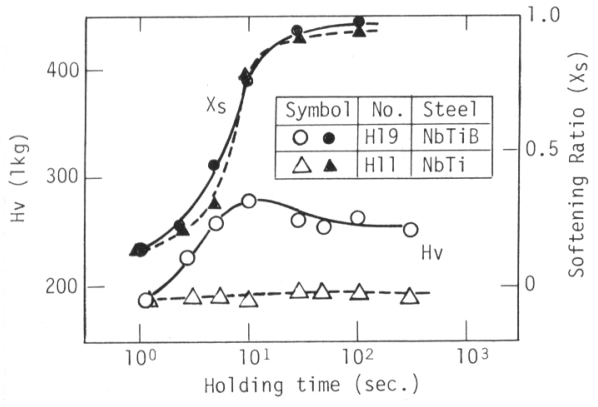

Fig. 6. Holding time dependency of hardness of $\mathrm{NbTiB}$ and $\mathrm{NbTi}$ steels quenched into liquid $\mathrm{He}$ after hot deformation comparing each softening behaviour.

が $\sigma_{1}$ より高くなるためである、NbTi 鋼においては保 持時間による強度変化は少なくほぼ一定で, その硬度值 は $\mathrm{NbTiB}$ 鋼の加工直後に $\mathrm{He}$ ガス焼入れした時の硬度 と一致する。これは加工再結晶途上からの焼入れでは B の焼入性向上効果を $100 \%$ 発揮することはできないこ と，およびその焼入性向上効果の発揮は $\gamma$ の再結晶後の 粒成長と B 原子の拡散による粒界偏析の競争に支配され ることを示唆するものである．また加工温度により当然 $\gamma の$ 再結晶挙動は異なり, 仕上温度が低くなるほど再結 晶は長時間側にシフトする。すなわち, 加工温度が $900^{\circ} \mathrm{C}$ から $800^{\circ} \mathrm{C}$ に変化すると $\mathrm{TiB}$ 鋼では再結晶まで の潜伏期が約 $7 \mathrm{~s}$ 増加し, NbTiB 鋼では明瞭な回復過 程を呈し $800^{\circ} \mathrm{C}$ 仕上げでは大きな再結晶抑制効果が発 揮されることが示される (Fig. 5)。これは Fig. 3 にお ける $\mathrm{TiB}$ 鋼の $800^{\circ} \mathrm{C}$ 仕上げは再結晶途上からの焼入れ であること, NbTiB 鋼では未再結晶領域からの焼入れ であることを意味する。 $\mathrm{NbTiB}$ 鋼と $\mathrm{TiB}$ 鋼の違いは $800^{\circ} \mathrm{C}$ 仕上げにあり, 未再結晶 $\gamma$ から直接焼入れする時 のBの焼入性向上効果と再結晶途上から直接焼入れする 時の Bの焼入性向上効果の差である.

\section{$3 \cdot 3$ 加熱温度の強度に及ぼす影響}

Fig. 7 に直接焼入鋼の強度の加熱温度依存性を $\mathrm{NbTiB}$ 鋼と $\mathrm{TiB}$ 鋼を比較して示す.両鋼種とも加熱温 度が $950^{\circ} \mathrm{C}$ から $1050^{\circ} \mathrm{C}$ と高くなると強度上昇を生じ る.これは初期 $\gamma$ 粒の粗大化と B化合物の分解によるB の固溶, $\mathrm{NbTiB}$ 鋼ではさらに $\mathrm{Nb}$ の固溶による B との 前述の相乗効果に起因する. しかし $1150^{\circ} \mathrm{C}$ に加熱温 度を上昇させると逆に強度低下を生じる．Photo. 4 に FTE 法によりBの分布状況を観察した結果を示す。 $1150^{\circ} \mathrm{C}$ 加熱時は他の加熱温度のものに比較して塊状の B 化合物の密度が増している. Photo. 1 に示すように

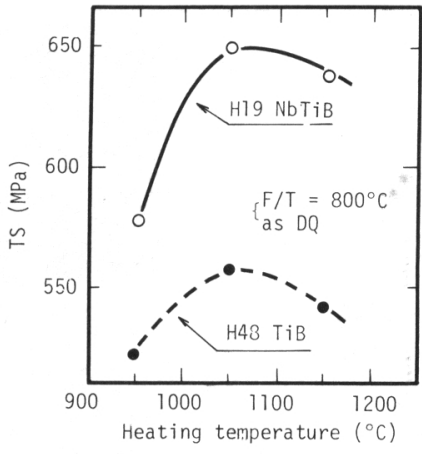

Fig. 7. Effect of heating temperature on tensile strength of direct quenched $\mathrm{NbTiB}$ and $\mathrm{TiB}$ steels.

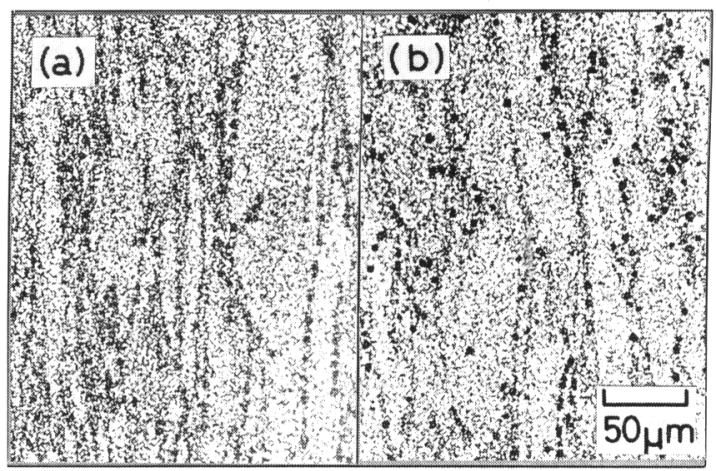

(a) $1050^{\circ} \mathrm{C}$ (b) $1150^{\circ} \mathrm{C}$

Photo. 4. Change indistribution of $\mathrm{B}$ atoms with heating temperature in direct quenched $\mathrm{NbTiB}$ steels.

加熱温度の上昇に伴い B 化合物は固溶し固溶 $\mathrm{B}$ は増加す るが，圧延中あるいは圧延後の冷却中に固溶 $\mathrm{N}$ と結合し BNを形成する。これを防止するため一般には Nに対し て化学量論的以上の $\mathrm{Ti}$ を添加する. Photo. 4 の鋼も Ti 添加された成分系である. Photo. 1 に示されるよう に Ti が化学量論的以上に添加されたとしても凝固時に 必ずしもNはすべて Ti に捕らえられて TiN を形成す るというのではなく一部は $\mathrm{BN}$ として存在する。これ は B と $\mathrm{N}$ の拡散速度の速さに起因する非平衡反応のため であ万う。しかし BN の固溶温度以上 $\left(1050^{\circ} \mathrm{C}\right.$, $\left.1150^{\circ} \mathrm{C}\right)$ の加熱時には, 固溶 $\mathrm{N}$ は熱力学的に安定とさ れる TiN として捕らえられるはずであるが Photo. 4 に 示すように $1150^{\circ} \mathrm{C}$ 加熱時でも塊状の B 化合物を形成 しているのが認められる. Photo. 5 に示すようにこの 旧 $\gamma$ 粒界上の塊状の化合物は BN であることが確認さ 


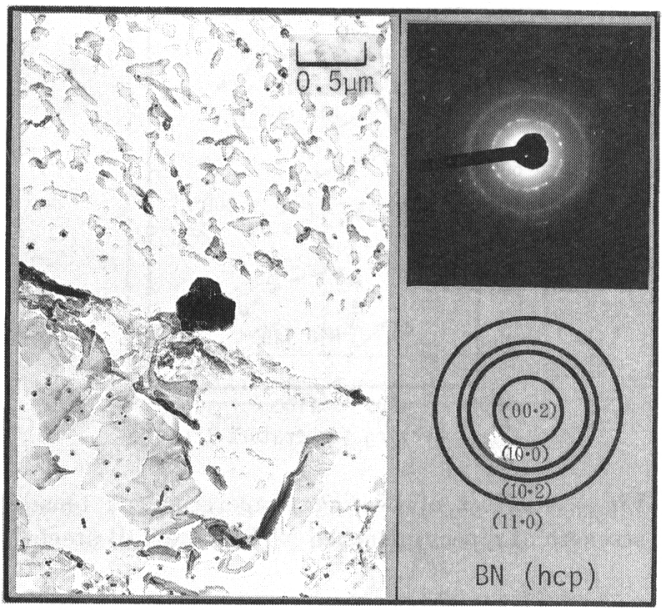

Photo. 5. Extration replica of $\mathrm{BN}$ precipitate at prior austenite grain boundary of direct quenched $\mathrm{NbTiB}$ steel which is heated at $1150^{\circ} \mathrm{C}$.

れている.これは次のように考えられる. $1150^{\circ} \mathrm{C}$ 加熱 時に生じる微量の固溶Nが粒界あるいは変形带を通じて パイプ拡散により粒界あるいは変形帯に偏析している固 溶 B と結合して $\mathrm{BN}$ を析出する。この固溶 $\mathrm{N}$ は $\mathrm{TiN} の$ 溶解度積 ${ }^{10)}$ から計算すると計算上約 $0.4 \mathrm{ppm}$ である が, $0.4 \mathrm{ppm}$ の固溶 $\mathrm{N}$ が生成したとしても $\mathrm{BN}^{11)}$ の溶解 度積からは直接焼入れする $900 \sim 800^{\circ} \mathrm{C}$ の温度域で BN を析出する可能性はない. しかし， $\gamma$ 粒界あるいは変形 带という局所での反応であり, 非平衡的な反応を通じて BN を形成することは十分考えられる，この反応は直接 焼入れする時に焼入性向上効果を発揮する $\gamma$ 粒界あるい は変形带に偏析している固溶Bを直接 BN として捕ら えるものでありその影響は無視できないと推定される.

Fig. 1 に示す $8 \mathrm{ppm}$ の極低 $\mathrm{N}$ 量の場合は $1150^{\circ} \mathrm{C}$ の高 温加熱しても強度低下は生じない。この場合 $1150^{\circ} \mathrm{C}$ 加熱時に生成する固溶 $\mathrm{N}$ 量は $0.2 \mathrm{ppm}$ であり, $19 \mathrm{ppm}$ $\mathrm{N}$ の場合の $1 / 2$ の固溶 $\mathrm{N}$ 量に相当する。絶対値そのも のからは $19 \mathrm{ppm} \mathrm{N}$ の場合では $0.3 \mathrm{ppm}$ の固溶Bを, 8 $\mathrm{ppm} \mathrm{N}$ 量の場合では $0.15 \mathrm{ppm}$ の固溶 Bを固定するこ とができる，両者とも本形態分析法の精度を下回る軽微 な量での議論であり，確認はできないが，本実験からは 前者は明らかにBの効果を減殺し後者は無視し得る量で あるという結果となっている。

\section{4. 考察}

$\mathrm{NbTiB}$ 鋼, $\mathrm{TiB}$ 鋼ともに $900^{\circ} \mathrm{C}$ 仕上げでは再結晶 $\gamma$ 粒界にBが偏析してBの焼入性向上効果が確認されてい

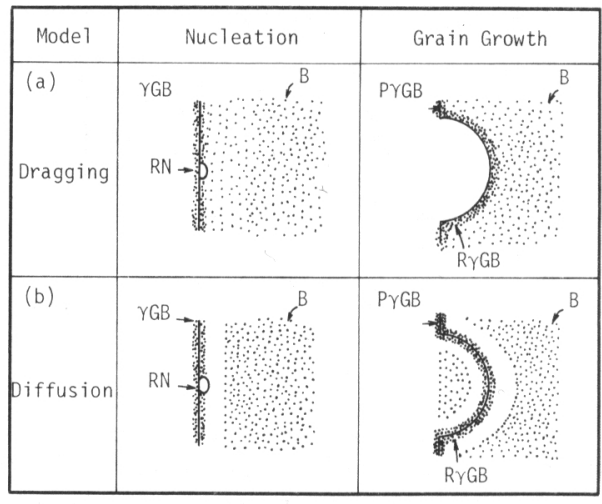

$\gamma_{\mathrm{GB}}$ : Austenite grain boundary RN : Recrystallization nucleus $\mathrm{P} \gamma \mathrm{GB}$ : Prior austenite grain boundary B:Boron atoms $\mathrm{R} \gamma \mathrm{GB}$ : Recrystallized austenite grain boundary

Fig. 8. Segregation models of boron atoms to austenite grain boundary in direct quenching process.

る. 再結晶から粒成長過程に扔けるBの粒界への偏析と しては ( a ) 粒界が B 原子を引き付けながら粒成長する Dragging type, ( b ) 粒成長が先に生じ後粒界付近のB 原子が粒界へ拡散により偏析する Diffusion type の二つ のモデルが考えられる（Fig. 8)，前者では粒界がB原 子を固着して移動し，かつ粒内に取り残されるB原子は 少なくなることを意味する，後者では再結晶後の粒成長 が飽和する時の粒界へ拡散により偏析することを意味す る. Photo. 3 からは粒内にB 原子が減少している様相 は認められず，逆に粒界近傍にはB原子が欠乏している と考えられる腐食の薄い領域が認められる. SELLARS $ら^{12)}$ は KoZASU et al. ${ }^{13)}$ と MILLER ${ }^{14)}$ の結果を用いた, 圧延加工による $\gamma$ の再結晶過程に书ける粒成長を次の上 うに定式化した。

$$
d^{10}=d_{0}^{10}+A^{\prime \prime} t \exp \left(-Q_{\mathrm{gg}} / R T\right)
$$

ここで $d$ は再結晶後の時間 $t(\mathrm{~s})$ に掞汀る $\gamma$ 粒径, $d_{0}$ は再結晶直後の $\gamma$ 粒径, $A^{\prime \prime}$ は定数, $Q_{\mathrm{gg}}$ は粒成長の活 性化エネルギー, $R$ はガス定数, $T$ は絶対温度である. (2)式を時間 $t$ で微分し粒成長速度 $G$ を求め Fig. 9 に 示した. 粒成長速度は加工後 $10 \mathrm{~s}$ では約 $0.1 \mu \mathrm{m} / \mathrm{s}$ で あり，本実験のような圧延後約 $10 \mathrm{~s}$ の焼入れでは再結 晶粒の粒成長は $\mathrm{B}$ 原子の拡散速度に比較すれば静止粒界 といえる. 同図中には B 原子の平均拡散距離を併記して いるが $900^{\circ} \mathrm{C}, 10 \mathrm{~s}$ で約 $14 \mu \mathrm{m}$ である. Diffusion type のモデルによれば，この粒界から $14 \mu \mathrm{m}$ の範囲に存在 する B 原子が粒界に偏析して焼入性向上効果を発揮する ことを意味する。再加熱焼入れにおいて焼入性を向上さ せるに必要とされる B量は 3〜 5 ppm あれば良いとされ 


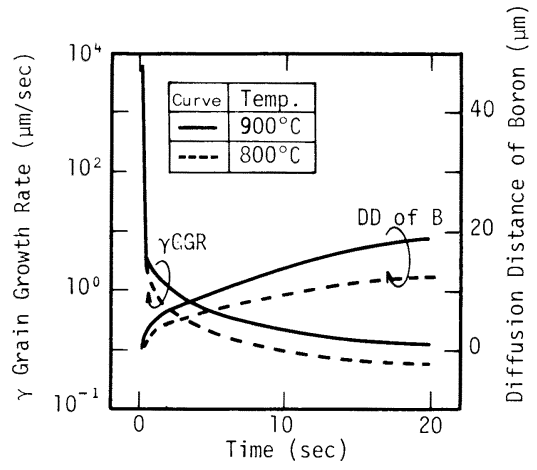

Fig. 9. Calculated $\gamma$ grain growth rate and diffusion distance of boron atoms.

ており，実験的にも確認されている ${ }^{15)}$. いま再加熱焼 入時の $\gamma$ 粒を 14 面体・粒径 $\left(D: D=1.06 d_{1}, d_{1}\right.$ は公称 粒径）を $30 \mu \mathrm{m}$ と仮定し $\gamma$ 粒界にBが $3 \mathrm{ppm}$ 偏析して いるとする.ここで $\gamma$ 粒の表面積は $(3+6 \sqrt{3}) D^{2} / 4$ で 表されるから ${ }^{16)}$, B 原子 1 個が $\gamma$ 粒界で占める表面積 は $6.02 \times 10^{-16} \mathrm{~cm}^{2}\left\{\doteqdot\left(2.45 \times 10^{-8} \mathrm{~cm}\right)^{2}\right\}$ となる。こ れは $\mathrm{Fe}$ 原子の最短原子間距離が $2.585 \times 10^{-8} \mathrm{~cm}$ $\left(950^{\circ} \mathrm{C}\right)$ であることから $3 \sim 5 \mathrm{ppm}$ の B 原子がすべて粒 界に偏析するとすれば，おおまかにいうと $\gamma$ 粒界面上の $\mathrm{Fe}$ 原子 1 個あたり $\mathrm{B}$ 原子 1 個存在することを示すもの である，本計算は 1 原子層と仮定したが, 実際は粒界垂 直方向に濃度プロフィールを持つこと等を考えると $\mathrm{Fe}$ 原子に対する $\mathrm{B}$ 原子の密度は数分の一一数十分の一とな り, 界面エネルギーを低下させる偏析原子の密度として 妥当な值と考えられる.ここで $\mathrm{NbTiB}$ 鋼の $900^{\circ} \mathrm{C}$ 仕上 時の約 $80 \mu \mathrm{m}$ の $\gamma$ 粒界に注目する. 体積は $\sqrt{2} D^{3}$ で示 されるから $80 \mu \mathrm{m}$ の $\gamma$ 粒中には $10 \mathrm{ppm}$ の固溶Bが存在 しているとすると粒界から $14 \mu \mathrm{m}$ の範囲には $2.8 \times 10^{11}$ 個のB原子が存在することになる. この全 B 原子が粒界 に拡散して偏析すると仮定すれば，B原子 1 個の占める 面積は $7.66 \times 10^{-16} \mathrm{~cm}^{2}=\left(2.7 \times 10^{-8} \mathrm{~cm}\right)^{2}$ である.こ れは先の B の焼入性向上効果を発揮するに必要な存在密 度にほぼ匹敵し，十分焼入性向上効果を発揮するに足り る量といえる.この計算結果抢よび Fig. 9 より二つの モデルのうち Diffusion type のモデルが実験結果に合致 している. Fig. 10 は NbTiB 鋼の直接焼入材から化合 状態別定量分析により求めた Sol. B (固溶Bに相当す る）と TSの相関を示す. 直接焼入プロセスでは 10 $\mathrm{ppm}$ 付近で最高の TS を示し, 再加熱焼入れで最適な 量より多くのBがなければ焼入性向上効果が $100 \%$ 発 揮されないことが示される. しかも仕上温度によりその

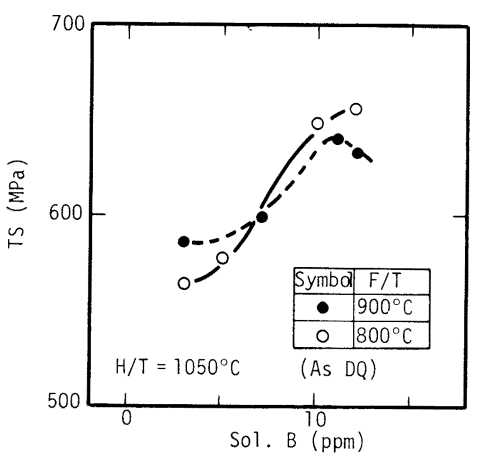

Sol. B $=$ Total B-Bas $(\mathrm{BN}+$ Boro-carbide $)$

Fig. 10. Effect of Sol. B on tensile strength of direct quenched $\mathrm{NbTiB}$ steels.

傾向が変化し, $900^{\circ} \mathrm{C}$ 仕上げでは $800^{\circ} \mathrm{C}$ 仕上げに対し, 低 Sol. B 領域で高 TS を示し高 Sol. B 領域で低 TS を 示す. かつ $900^{\circ} \mathrm{C}$ 仕上げでは $10 \mathrm{ppm}$ 付近に極值が存在 するのに対し， $800^{\circ} \mathrm{C}$ 仕上げではさらに高 Sol. B 側へ 移行する様相を呈している．直接焼入プロセスに扔ける $\mathrm{B}$ の焼入性向上効果の発揮とは粒界移動と B の拡散によ る粒界偏析の競合に支配される速度論的な議論となるた め, 従来の再加熱焼入れにおける平衡状態の B を活用す る場合より多くなることは定性的に理解され，かつ上記 の計算結果からも $10 \mathrm{ppm}$ 付近に最適值が存在すること は妥当といえる. Fig. 10 の低 Sol. B 領域で $900^{\circ} \mathrm{C}$ 仕 上げが $800^{\circ} \mathrm{C}$ 仕上げに対して強度が高いのは再結晶 $\gamma$ と未再結晶 $\gamma$ の焼入性の差といえる. 高 Sol. B 域で $800^{\circ} \mathrm{C}$ 仕上材の強度が高くなるのは, 未再結晶 $\gamma$ 域から の焼入れのため粒界の移動がなく静止 $\gamma$ 粒界面に継続し た偏析が可能となること, および変形帯が導入されても $\mathrm{B}$ の偏析が生じフェライトの生成が抑制されるためであ る.また $800^{\circ} \mathrm{C}$ 仕上材の最適 B 領域が高 B 側に移動す るのは, Bの拡散速度の差および変形带導入による B 偏析しうる界面積の増加に起因する. Fig. 11 は仕上温 度における固溶Bが焼入性に寄与すると仮定し, 計 算 $^{17)}$ によりもとめた固溶 $\mathrm{B}$ 量で $\mathrm{TiB}$ 鋼の直接焼入時の TS を整理したものである. $\mathrm{TiB}$ 鋼では $\mathrm{NbTiB}$ 鋼と違 い全 Sol. B 領域にわたり $800^{\circ} \mathrm{C}$ 仕上材が $900^{\circ} \mathrm{C}$ 仕上材 より低 $T S$ 側に位置している. TiB 鋼では $\gamma$ の再結晶 抑制効果は期待できないため, 圧延中あるいは压延後 $\gamma$ は再結晶過程にある. $800^{\circ} \mathrm{C}$ 仕上げでは再結晶までの潜 伏期が長く（Fig. 5), 仕上圧延後 $10 \mathrm{~s}$ で水冷開始する 本実験では再結晶途上からの焼入れとなり, 再結晶粒界 への十分な $\mathrm{B}$ の偏析ははかれない.そのため $\mathrm{TiB}$ 鋼の 低温 $\gamma$ 域仕上圧延ではBの焼入性向上効果を $100 \%$ 発 


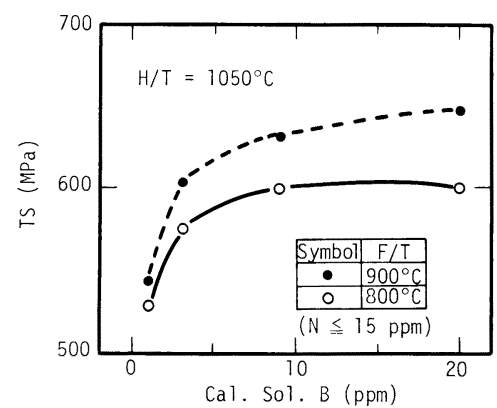

Fig. 11. Effect of Cal. Sol. B on tensile strength of direct quenched TiB steels.

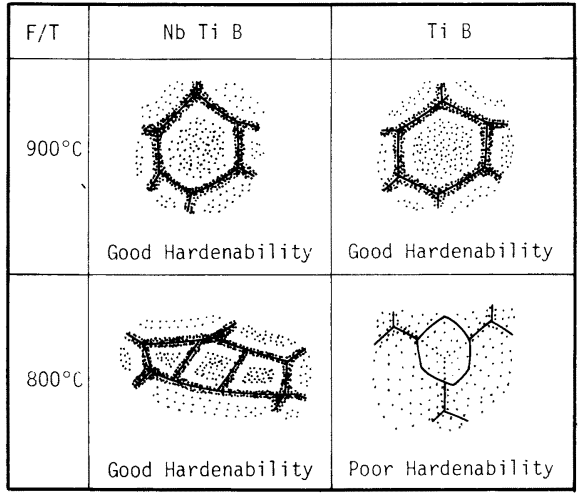

Fig. 12. Schematic distribution of boron atoms in direct quenched $\mathrm{NbTiB}$ steels at various finishing temperature.

揮できず NbTiB 鋼のような逆転現象は生じない. Fig. 12 に $\mathrm{NbTiB}$ 鋼と TiB 鋼の直接焼入プロセスにおける 焼入性と Bの粒界偏析の相関を模式的に示す．Bの焼入 性は粒界あるいは変形帯等に偏析しフェライトの生成を 抑制することにより発揮されるため，粒界の移動を阻止 するような再結晶抑制効果を有する $\mathrm{Nb}$ の添加は低温 $\gamma$ 域まで安定して Bの焼入性向上効果を活用しうる。一方, $\mathrm{Nb}$ のような再結晶抑制効果を有す微量添加元素を含有 しない成分系では，Bの拡散速度を速め偏析しうる界面 積を減少させ，かつ短時間で再結晶粒の粒成長が停止す る高温仕上げが焼入性確保に有効な手段となる.

\section{5. 総括}

直接焼入プロセスにおけるBの焼入性向上効果を検討 するため， $\mathrm{Nb}$ 量および圧延仕上温度を変えることによ りの再結晶挙動とBの粒界偏析の観点から考察し,
$\mathrm{NbTiB}$ 鋼と $\mathrm{TiB}$ 鋼の焼入性の差を明らかとした。

( 1 )直接焼入プロセスにおけるボロン鋼の焼人性は, $\mathrm{Nb}$ と共存すると低温 $\gamma$ 域まで安定した高い焼入性を発 揮する。これは $\mathrm{Nb}$ の再結晶抑制効果により界面の移動 が止められ， $\gamma$ 粒界面および压延加工により導入された 変形带へ継続してボロンの偏析を叮能とするためであ る。

( 2 )直接焼入プロセスにおいてボロンの焼入性们上効 果は仕上温度における固溶Bにて評価してょく，約 10 ppm 付近に最適の焼入性発揮領域が存在する.

( 3 ) 上記の結果は固溶 B 3 5 ppm で最大の焼入性向 上効果を示す SIMCOE らの結果を否走するものではなく, 直接焼入プロセスでは非平衡論的な取扱いとなるため $\gamma$ 粒界，変形帯に偏析する固溶Bの他，粒内に残される固 溶Bをさらに加味する必要性があることを意味する。

(4)再結晶抑制効果を有寸微量添加元素を持たない成 分系での直接焼入プロセスでBの焼入性向上効果を活用 するには，Bの粒界偏析量を最大にするため Bの拡散速 度を速め偏析させる界面積を減少させかつ短時間で再結 晶粒の粒成長が停止する高温仕上げが有効である。

\section{文献}

1) Ph. Maitrepierre, $D$. Thivfllie and $R$. Tricot: Metall Trans. A, 6 (1975), p. 287

2 ) たとえば, 井関祥浩, 済木捷郎, 大谷泰大, 渡辺征一: 住友金属誌，27 (1975), p. 399

3 ) 渡辺征一, 大谷泰夫, 邦武立郎: 鉄と鋼，62（1976）, p. 66

4 ）今中 誠, 杉江英司, 上田修三: 鉄と䤱, 70 (1984), $\mathrm{S} 634$

5 ) 小関智也, 寺嶋久栄, 志賀千晃: 鉄と鋼, 73 (1987), A 291

6 ）鎌田芳彦, 蔵保浩文, 渡辽征一: 鉄と鋼, 73 (1987), A 295

7 ）渡辺征一: 日本金属学会会報, 19 (1980), p. 804

8 ) 仲山 剛, 猪熊康夫, 蔵保浩文: 鉄と鐦, 72 (1986), $\mathrm{S} 1300$

9 ) 大内千秋: 鉄と鋼, 70 (1984), p. 2081

10) 成田貴一: 日化誌, 77 (1956), p. 1536

11) P. E. Bushby, $C$. Wells and $M$. E. Warga: Trans. AIME, 197 (1953), p. 1463

12) C. M. Sellars and J. A. Whiteman: Met. Sci., 13 (1979), p. 187

13) I. Kozasu, C. OUCHI and T. Окіта: Microalloying 75, Vol. 1 (1975), p. 120 [New York Union carbide]

14) O. O. Miller: Trans. Am. Soc. Met., 43 (1951), p. 260

15) $C$. $R$. SimcoE, $A$. $R$. Elsea and $G$. $K$. Manning: J. Met., 8 (1986), p. 984

16）梅本 実, 田村今男: 熱処理, 24 (1984), p. 334

$17) R$. Habu, $M$. Miyata, $S$. Sekino and $S$. Goda: Trans. Iron Steel Inst. Jpn., 18 (1978), p. 492 